\title{
研究委員会企画シンポジウム
}

\section{I 「教育心理学の研究・教育における遺伝学の役割」}

$\begin{array}{llllll}\text { 企画 ・司会者 } & \text { 子安 } & \text { 増生 } & \text { (京 都 大 学) } \\ \text { 話題提供者 } & \text { 河田 } & \text { 雅圭 } & \text { (静 岡 大 学) } \\ & \text { 安藤 } & \text { 寿康 } & \text { (慶 應 義 塾 大 学) } \\ & \text { 小嶋 } & \text { 秀夫 } & \text { (名 古 屋 大 学) } \\ \text { 指定討論者 } & \text { 岩井 } & \text { 勇児 } & \text { (愛 知 教 育 大 学) } \\ & \text { 矢野 喜夫 } & \text { (京 都 教 育 大 学) }\end{array}$

\section{企画の主旨}

\section{子安 増生}

近年の遺伝学研究の進歩には，瞠目すべきものがある。 分子生物学からは, D N (デオキシリボ核酸)を媒介とし た遺伝情報の伝達と，その過程での様々な擾乱のメカニ ズムが明らかにされてきた。また，行動遺伝学からは， 生物集団における特定の形質の遺伝的伝播の仕組みが計 量的に説明されるようになってきた。さらに，社会生物 学からは，様々な動物の行動を “支配”する遺伝子の仕 組みが明らかにされ，ドーキンス，R．により「利己的 遺伝子」という概念が提唱されている。

このような研究から明らかにされた遺伝の機構は，成 長・発達や老化・死などの心理学的現象に直接関与する のみならず (例：「プログラム死」の概念)，性差や個人差な どパーソナリティの源泉になっていることは明らかであ る。また，わが国でも緊急性の高まっている A I D S (後 天性免疫不全症候群)に関する教育を考える上でも，たとえ ば「レトロウィルス」「逆転写酵素」などといった遺伝学 的知識が欠かせない。

諸外国では, 教育心理学の研究・教育において遺伝学 的知識が不可欠であることは比較的早くから認識されて きた。ところが，わが国の教育心理学の研究・教育の現 状を眺めると,このような遺伝学の知識が十分に取り入 れられているとは言いがたい。最近この点に関して, 生 物学者の河田雅圭は, 雑誌『現代思想』に「心理学・教 育学の生物学的基盤は大丈夫か？」という論文を発表し, 教育心理学などの研究における遺伝観や遺伝的知識の不 確かさを批判した(河田，1992)。このような問いかけに対 して，教育心理学からはどのような答を示すことが可能 であろうか。

また，昨年 (1992年) の日本教育心理学会第35回総会で は, 日高敏隆・京都大学理学部教授（当時）により, 準備
委員会企画特別講演「エソロジーと現代」が行われ，比 較行動学の成果が人間観の形成に与えてきた影響が語ら れた (教育心理学年報」第32集に講演要旨揭載)。その中では, 学習も遺伝的に規定された行動であるという考え方が示 されている。このことに対する教育心理学からの見解も 当然示さなければならないであろう。

このような時期にあたり, 教育心理学の研究・教育に おいて遺伝学が果たす役割に関して, 教育心理学会とし て学会レベルでの議論と意見交換を行うことは，きわめ て有意義であると考えられる。本シンポジウムは, この ような趣旨から企画されたものであるが，特に次の 2 点 について議論を深めることを目的とした。

（1）教育心理学の研究・教育において必要とされる遺伝 学的知見とは何か?

（2）遺伝学の理論と事実は，人間観，発達観，教育観な どにどこまで影響を与えうるか?

\section{生物学的観点からみた教育心理学}

河田 雅圭

教育学・心理学が人間の発達 (発生) や人間の生物学的 な特性について言及することは少なくない。さらに，人 間の生物学的特性をもとに教育観や教育法を考えようと する教育学者・心理学者も多い。特に, 行動, 進化, 発 生, 遺伝といった事柄は, 生物学的な問題であり, 教科 書のなかでも触れられることが多い。しかし, 日本の教 育学, 心理学, 発達心理学, 教育心理学の教科書の中で 記載されている生物学的な記述は, 現代の生物学ではほ とんどとりあげられることがないような生物学者の説明 が主流をなしていたり，不正確な記述部分が多い。

現代生物学のなかでも，人間の特性に関して説明でき る完全な理論があるわけではない。また，教育学者・心 理学者が，自らの立場で生物学的問題に言及することは, ときには重要な場合もある。しかし、「完全に正しい生物 学の理論はない」「完全にあやまりとはいえない」という 理由だけで, 自らの生物学的解釈の根拠を述べずに, 多 くの生物学者が誤りであると考えている理論を中心に心 理学や教育学の中だけで, 自らの意見を主張したり, 教 科書に記載したりすることは適切ではない。生物学の中 では, いくつかの主流な理論が，新しく報告される実験 
や観察事実から検証が行われているのである。もちろん， 生物学者のなかにも, 主流ではなく, 誤りであると思わ れる考えを記載する人は少なくないが，それらは，他の 生物学者から批判をうけたり, また, 主流ではない一部 の考えとして認識されている。従って, 教育学者や心理 学者が独自の生物学的解釈を行うときは, 生物学の中で, その考えの評価を受けるべきである。

また, 教育学・心理学の生物学的解釈で問題になる点 は, 自らの教育論に都合のよい生物学的解釈をする教育 学者が少なくないという点である。たとえば, 人間にお ける教育の役割を強調するあまり, 様々な人間の特性の 間にみられる遺伝的な差を軽視, あるいは, 否定する場 合が少なくない。しかし, 現在, 分子生物学の発展によ り，人間の様々な性質の遺伝的基盤があきらかにされつ つある。特に病気や障害に関わる遺伝子は特定されはじ めているし, 行動などに関わる遺伝子や遺伝的要因を特 定したとする研究もある。そのような研究の真偽に関し ては, とくに慎重に判断をしていかなくてはならないと 同時に, 今後, 人間の様々な特性の遺伝的な差が明らか になることを予想し, 遺伝的な差が差別や人間の価值の 差につながらないような教育を考えていくことがより重 要になってくるであろう。

\section{新しい遺伝概念を求めて}

(Toward a new concept of "heredity")

\section{安藤 寿康}

教育の視座の中で, 遺伝という概念をタブー視するの ではなく，むしろ「遺伝的規定があるからこそ人間の発 達可能性はかくもすばらしい」という積極的価值転換を 行えないものだろうか, とずっと考えている。教育とい う世界は, 基本的に人間の可能性の開花というロマンを 求める人々の集まりである。このロマンに水を差すよう な命題は, いかに科学的な正当性をもっていても無視さ れやすい(もちろん挑戦という形で研究が進歩するケースもある ことは否定しない)。個人差の「遺伝」がそうであった。と ころがこの同じ「遺伝」概念が，新生児の生得的有能性 という話題だと歓迎される。身勝手な話である。この身 勝手さを内部告発する（？）というのも筆者の意図には 含まれている。このような姿勢に基づく教育心理学的研 究は, 結局自らの科学的価值を低めるであろうという危 惧があるからである。そもそも自然を敵に回すのは賢明 なことではなかろう。特に生命科学が急速に進歩しつつ ある現在, 遺伝に対して今のようなナイーヴな対応をし ていたら，早晚足をすくわれることになることは目に見 えている。しかし教育心理学者としてのアイデンティ ティは, 当然のことながらやはり教育的ロマンを求めて
いるのであって, そこで考えている戦略が, 人間行動遺 伝学の成果を正当に評価した上で A T I パラダイムとの 統合をはかるというものである。

「遺伝」という概念には「決定的」「伝達的」「不変的」 という身も蓋もないニュアンスがつきまとう。だが行動 遺伝学が扱う遺伝的影響は個人差という相対的側面につ いてであり, 発達の一般的プロセスではない。従って絶 対的な意味での決定性という意味はもたない。しかも教 育が関与するのは発達のプロセスなのである。発達の「プ ロセス」と個人差への「効果」は区別されるべきであり， 遺伝と環境はプロセスとしては「相互作用的」だが, 効 果は研究の現状では主として「加算的」とするモデル $(\mathrm{P}=\mathrm{G}+\mathrm{E})$ で破綻しないのである。相関や交互作用の効 果は今後の検討が待たれる。遺伝要因も基本的にポリ ジーンという加算的モデルで説明可能である。しかし パーソナリティや精神病理では遺伝子間の高次交互作用 (非加算的効果あるいはエマージェニックな遺伝)が見られる。 このような遺伝様式は表現型レベルでは伝達性がない。 さらに表現型の発達には時間的遺伝子の影響や，環境の 劇的変化にともなう新しい遺伝効果の出現などがある可 能性が示唆されており, 人間の心理的形質は発達を通じ てダイナミックな遺伝的影響下にあると考えられる。

人はひとりひとり異なる遺伝子型をもち, それに自律 的に規定されている。行動遺伝学がもたらすもっとも大 きなメッセージは, 悲観的宿命論ではなく, 人間の個体 性の「のっぴきならなさ」への認識である(人間行動遺伝学 では同時に環境の個体性一非共有環境一の重要性も示唆している)。 この認識は(論理的飛躍はあるが)「ひとりひとりに固有な豊 かな内的資源」への確信にもつながるものである。筆者 が双生児統制法による英語教授実験で示した安定したA T I も，この認識を支持するものとして解釈したい。

\section{発達心理学からの提言}

\section{小嶋 秀夫}

心理学の学習と研究の基礎として, 生物学や遺伝につ いての関連知識を組み込むことには意味があるが, かん たんには行かない。心理学者がそれを「勉強」して, 専 門領域に関する記述と統合してテキストや授業にまとめ 上げるのは大変である。生物学の専門家に依頼するにし ても，学問間の実効あるコミュニケーションには困難が 多い。今のところ, 生物学と心理学との直接的なやりと りを図るよりも, 領域間の相互作用のためのインター フェイスづくりの方が重要である。歴史的に見ると, 心 理学が生物学の進歩に刺激されたのは今回が初めてでは ない。発達心理学の創始者や発達理論の大家たちが, 進 化理論としては時代遅れの側面に惹かれた可能性はある。 
かれらも進歩思想と歴史主義という大きな潮流の中で生 まれ理論展開をしたことを考えると, 発達理論の主流が そのような選択をするように導かれ，最新の生物学から は距離をとった独自の道を辿ったことは理解できる。現 在でも遺伝学の理論と知見を直接に心理学の問題につな げることはできないと思う。発達心理学には，個体を中 心において，それと環境との間のインターフェイスおよ び生物学的条件との間のインターフェイスにどのように 焦点を当てて行くかが問われている。

(1) ヒトが一般に特有の心理学的発達のコースを辿るの はなぜか (系統発生的視点)；(2)特定の時代・社会の中で育 ち・生活する人々に特有な心理学的発達の特徵はなぜ生 じるのか (歴史的・文化的視点)；そして，(3)上記の 2 つの制 約条件の動きにもかかわらず個人がそれぞれ特徴をもっ た人間になるのはなぜか (独自性の形成) という 3 つの問い は, 人となる「ビカミング」の過程に関した発達的問い である。第 1 の問答に, 進化理論あるいは遺伝の機構に 関する知見が直接に寄与することがどれほど可能かは疑 問に思える。心理学の理論が生物学的遺伝のシステムと 矛盾するものであってはならないが, 遺伝学の上に心理 学が成り立っているのではない。これまではむしろ, 進 化理論や遺伝学そのものよりも, 生物学のシステム論的 思考が発達心理学の理論を展開させる上で有用であった。 第 2 の問いは文化的価值とかかわるものであり，問いの $1 も 3$, その影響を強く受けて設定される。この文化 的価值は, 特定の時代の特定の社会集団を成り立たせて いる種々の基礎条件と相互規定的な関係をもち，しかも 文化には歴史性がある。この視点を抜きにすると，心理 学的属性の遺伝の研究も迷走する可能性がある。心理学 がいちばん力を発揮すべき第 3 の問いは, 発想と方法論 の制約のため, 心理学の大の苦手となっている。人間行 動遺伝学の静的な分析手法は, この問いに直接答えるも のではない。当面は人々の独自性の記述法を工夫するこ とと，どのようにしてそのような人になってきたかにつ いての本人または関係者の語りをうまく引き出し，その 構成を援助する努力を続けることくらいしか思いつかな い。今のところ, 心理学者が遺伝学の知識をもっても, 独自性形成の語りが大きく進展するとは思えない。

\section{遺伝的視点を無視しないように}

\section{指定討論者 岩井 勇児}

安藤の指摘した「人間行動の遺伝に対する誤解と偏見」 は, 教員養成大学の学生にも深くしみ込んでおり, 遺伝 的視点から人間を考えることに，情緒的反発がある。そ して, 遺伝と環境についての知識と洞察力を欠くまま教 員となって，能力や個性を無視した特訓をしたり，でき
ない子供を㤐惰と遺伝のせいにして馬鹿にし傷つけたり することが起きている。しかも, 教育心理学や発達心理 学は,こうした誤解と偏見を是正するどころか, かえっ て助長しているような気がしてならない。

河田がテキストのレベルで指摘した問題は, 心理学者 の生物学についての無知や勉強不足によるだけではない。 心理学者の人間観, 発達観, 教育観の貧困にもよる。戦 時中から今にいたる教育心理学や発達心理学の教科書や 論文等のテーマなどを眺めると, 心理学の側からその時 代の教育を動かすというよりも，時代の流れのお先棒を かつぐような分野の研究や論説が流行っている。それは, 心理学者が本音で人間をみようとしないで, その時代に 流行している心理学の枠組みの建前からしか人間を見て こなかったからではないか。

多くのテキストは, 前置きで相互作用説を述べている が，それは建前にすぎず, 各論で相互作用の具体的記述 はほとんどなく, テキスト執筆の文脈の底辺には根強く 環境説が流れている。また, たとえば，親子関係と子供 の行動を扱うのに，単なる相関の記述にすぎないデー夕 を親の与える環境が子供の行動の原因のように解釈し, 子供の遺伝子が子供の行動に影響し，それが親の行動に 影響している，といった発想でデータを見る研究はあま りない。データの忠実な解釈としては, どちらの発想も 成り立つのではないか。たしかに, 個人の発達という単 位で考えてみると, 特定の個人の発達に遺伝が関与して いる証拠はない。しかし，遺伝説に対する批判と同じ論 法で, 環境説のデー夕をみると, 特定の個人の発達に環 境が関与している証拠もないのである。

教育心理学の研究・教育の底辺を流れる環境説が, 塾 や学校の早期教育や教育過㮃の弊害を暗々裏に助長して いるとすれば, 教育心理学や発達心理学は害毒を流して いることになる。ここから脱却するためには, 近代合理 主義に基づく「子供は人の力で産み育てる」という発想 から，昔から伝えられた「子供は天からの授かりもの」 という発想に回帰する必要がある。つまり「最良の環境 を与える」といった思いあがりを捨てて，人の操作を越 えた遺伝子が個性や主体性の源泉であり，最良の環境は 一概に決められないという, 遺伝的視点から心理学を見 直す必要がある。ただし, 遺伝的視点の危険性を防ぐた めには,「素質を最大限に発揮することが善である」とい う視点を捨てて, どんな発達の仕方をしても，その個人 にとっては, かけがえのない発達だとみる視点が必要で ある。つまり, 教育や発達に関して,「失敗」や「無駄」 という視点を破棄することである。 


\section{3 氏の講演へのコメント}

\section{指定討論者 矢野 喜夫}

河田雅圭氏は生物学の立場から, 心理学・教育学で取 り上げられている生物学的事実や理論に誤解や偏り, 新 しい研究の進展の知識不足があると論じておられる。た しかにそのような事実はあるが，この問題は生物学対心 理学の学問間の集団的な対決ではなく, 個人ベースの議 論によって学問間のインターフェースを作るべきだと思 う。

氏の, 新しい理論が古い理論より正しいという考えに は疑問がある。生物学でも心理学でも, 研究や理論には 動向や流行というものがあり，私たちは古いものも新し いものも並列させて判断すべきである。氏は, 最近の生 物学ではローレンツの理論や今西理論はまちがいだと断 定されるが, それらにはいろいろ問題あるとか議論があ るというべきで，簡単にまちがいだと断定すべきではな い。

氏は, 教育・心理学で原理として用いられている生物 学的原理はデー夕による検証を受けていないことが多い と言われる。たしかに生物学的事実や理論を安易に発達 論や教育論に結びつけるのは危険であるが, 発達心理学 は生物学に基礎をもち, 多くの概念を生物学の発生学や 進化論などに負っている事実がある以上, 発達心理学に とって生物学的知識は不可欠であり, そのとき, まだ検 証されていない生物学の仮説や理論を取り上げてはいけ ないということはない。学問は仮説や理論から始まり, 検証は後でなされるものであるから, それを検証されて いるかのごとく語るのは許されないが, 仮説を仮説とし て理論を理論として取りあげることは許される。また, 生物学的事実や理論にもとづいた教育論は危険性がある という主張は, 一方で教育学・心理学がたしかな生物学 的知識に基づくべきであるという主張と一見矛盾するよ うに聞こえ，両者は微妙な関係になる。

氏は, 種としての共通性という考えは不適切であり, その考えでは遺伝的変異は異常と等しくなると言われる が, 種としての人間の普遍性や共通性は現に存在するし, そうでなければ心理学は不可能である。それは遺伝的変 異や個人差の存在と矛盾はせず, 変異と異常とは違う。 また氏は，教育では個人差をタテマエでは否定している と言われる。たしかにそういうことがあるが, 個人差で なく個性となると, むしろ教育のタテマエでは個性を尊
重すると言いながら，実際には少しも尊重されていない ということがあり，個人差と個性は夕テマエとホンネで 逆になっていることに注意すべきである。

安藤寿康氏は新しい人間行動遺伝学の立場から, ダー ウィン, ゴールトン以来の個人差の遺伝の問題を, 一卵 性・二卵性双生児を使って観察可能な表現型の水準で定 量的に分離して，分散分析モデルにおける分散の加算性 と要因の交互作用の問題として研究しうることを示され た。そのとき，人間行動遺伝学が扱うのは結果としての 個人差の問題であり, 発達プロセスの問題ではないと自 己限定しておられる。しかし発達心理学の立場からは, やはり発達プロセスが問題になる。発達行動遺伝学とい うのもあるようだが, それはいかにして可能なのか知り たい。たとえば，氏は知能の遺伝率の問題のとき，知能 をI Q あるいは知能偏差值でとらえておられると思う。 しかし発達心理学としては知能をむしろMAでとらえた いが，そのときはどうなるのか。

遺伝効果は加算的なものと非加算的なものとがあると 言われるが，それらが分散分析モデルの中でどのような 関係にあるのか疑問に思う。また遺伝は必ずしも親子で 伝達しないといわれるが, それは表現型の問題であり, 遺伝子型では伝達するのではないか。

氏が遺伝を, 個人の潜在的可能性としての内的資源と してとらえたいと言っておられることには同感する。

小島秀夫氏は発達心理学の立場から, 遺伝子型と表現 型の問題, 個人差と独自性の問題, 異文化間の差異の社 会・歴史面と遺伝的素質面, 心理的発達面の水準の問題 を論じられた。氏は生物学的問題に専門外の心理学者が 取りあげるのは危うさがあるので, 触れないほうが賢明 だと言われるが, 発達心理学では生物学的概念を避けて 通れないし, 科学的真理の平等性・解放性ということか ら, 生物学者と心理学者は専門性を越えて理解し論じ合 うべきだと思う。

日欧比較における発達の違いの水準については, 違い だけでなく人間として共通する面もあるはずであり, 相 違と共通性の両者を考えるべきではないか。結局人間に は, 個人間の比較による個人差 (変異) と, 個人内の組織 化による個性 (独自性) と, 種としての人間の共通性 (普遍 性)があるのであり, それらをいかにとらえるかというこ とが心理学の課題だと思う。 